\title{
Characterization of Thermostable Amylase From Halophilic Lactobacillus Plantarum TS1
}

\section{Sania Riaz}

COMSATS University Islamabad

\section{Anum Fareed}

COMSATS University Islamabad

\section{Habiba Zaffar}

COMSATS University Islamabad

\section{Shafique Ur Rehman}

University of Haripur

\section{Muhammad Jamil}

Kohat University of Science and Technology

\section{Ismat Nawaz}

COMSATS University Islamabad

Iftekhar Zeb

COMSATS University Islamabad

Jamshaid Hussain

COMSATS University Islamabad

\section{Raza Ahmed}

COMSATS University Islamabad

Tatheer Alam Naqvi ( $\square$ tatheer@cuiatd.edu.pk)

COMSATS University Islamabad https://orcid.org/0000-0003-4538-6317

\section{Research Article}

Keywords: Halophiles, Amylase, Thermostable, Kinetics

Posted Date: June 7th, 2021

DOl: https://doi.org/10.21203/rs.3.rs-565599/v1

License: (9) This work is licensed under a Creative Commons Attribution 4.0 International License. Read Full License 


\section{Abstract}

Amylase is an important enzyme use extensively in various industrial processes. It is mainly involved in the catalysis of starch that requires harsh conditions; therefore, it is required to isolate amylases with unique properties that makes it more applicable. Extremophiles are the major resource of such enzymes; therefore, amylase positive strains were isolated from the saline soil where the temperature is also exceptionally high. Five amylase positive strains were isolated from the Karak salt range, Kohat Pakistan and were identified by phylogenetic analysis. DNS based assay was employed to compare the activities of different amylases obtained from five strains while using the starch as a substrate. The amylase obtained from Lactobacillus plantarum TS1 was found to be more efficient, which was purified and characterized. The SDS-PAGE of purified amylase showed a single band with an estimated size of 10 $\mathrm{kDa}$. The kinetic parameters were measured at two temperatures i.e. at $37^{\circ} \mathrm{C}$ and $50^{\circ} \mathrm{C}$. The $K_{\text {cat }}$ as well as the $K_{\text {cat }} / K_{M}$ were found to be high when temperature increased from $37^{\circ} \mathrm{C}$ to $50^{\circ} \mathrm{C}$. Amylase was active at wide range of temperature as well as $\mathrm{pH}$ and work efficiently in the presence of salts and various organic solvents.

\section{Introduction}

Extremophiles are strange microorganisms having ability to grow and survive in extreme environments, which were once considered too hostile to support life. Extremity of environments are well-defined by extreme conditions such as $\mathrm{pH}$, salinity, temperature and many other soil conditions or combinations of these conditions (Rothschild and Mancinelli 2001). The set of organisms that specifically inhabit and adapt these extreme environments are designated as thermophiles, acidophiles, alkaliphiles and halophiles depending on the type of extreme environment conditions they inhabit (Ulukanli and Digrak 2002). The extremities of these environmental conditions at which life can flourish have not been defined exactly so far. The extremophily is a relative concept as conditions which are 'extreme' to one group of organisms might be crucial to other's survival. Extremophiles belong to all three domains of life viz., bacteria, archaea and eukaryotes (Irwin et al. 2004). Hypersaline environment forms a representative pattern of environment with harsh conditions due to its high salinity, low oxygen conditions, extreme temperature and in few cases, extreme $\mathrm{pH}$. Although salts are necessary for all life forms, those extremophilic microorganisms that are specialized for living in hypersaline environments are known as halophiles (Shafiei et al. 2012) These organisms can be categorized on the basis of level of their salt requirement for optimum growth: slight halophiles requires $0.2-0.85 \mathrm{M}(1-5 \%)$ sodium chloride $(\mathrm{NaCl})$; moderate halophiles requires $0.85-3.4 \mathrm{M} \mathrm{(5-20 \% )} \mathrm{NaCl}$ and extreme halophiles require 3.4-5.1 M (20$30 \%) \mathrm{NaCl}$ (Dalmaso et al. 2015).

The use of enzymes or microorganisms as biocatalyst is well documented to produce various products (Irwin and Baird 2004). Owing to the utilization of many harsh process conditions in various industries, there is a considerable demand for biological catalysts that can withstand the conditions of such processes. Most of the enzymes used until now originate from mesophilic microorganisms and despite of their many advantages, the usage of these types of enzymes is restricted because of their inadequate 
stability at the extreme process conditions. On the other hand, extremophilic microorganisms are a potent source of extremozymes which show extreme stability at various harsh conditions. Extremozymes are biocatalysts which can remain active at extreme conditions that were earlier considered as incompatible in biology (Gomes and Steiner 2004). These extremozymes possess high economic potential. A vast variety of hydrolytic extremozymes are produced by halophilic bacteria into its nearby environment. The search for these extremozymes with novel activities at extreme conditions and enhanced stability continues to be a priority aim in enzyme research (Dumorne et al. 2017).

Halophilic proteins depend on salt for their proper folding. To fulfil this, these proteins have some general adaptations such as minimum number of hydrophobic residues, greater number of acidic amino acids on surface of proteins and peptide insertions in proteins that could enhance the enzyme flexibility (Brininger 2018). Negative charges present on halophilic enzymes surfaces bind greater number of hydrated ions, therefore decreasing their hydrophobicity at the surface and reducing the chances to form aggregate at a higher salt concentrations (Gomes and Steiner 2004). Such adaptations contribute in keeping these halophilic proteins stable in extreme conditions and allows halophilic organisms to thrive in these conditions which are usually unfavourable to other organisms. Such properties of halophiles and their enzymes make them an attractive and remarkable source in biotechnological research (Brininger 2018).

Amylases are the hydrolytic enzymes having ability to degrade starch to yield dextrins and eventually to glucose monomers. These can be further categorized into endo-amylases (a-amylases) and exoamylases ( $\beta$-amylases) (wang et al. 2019). Amylases have excessive importance for biotechnological applications and comprises about $25-30 \%$ of the global enzyme market (Rajagopalan 2008). Amylases from halophiles are among such type of extremozymes that show polyextremophilic properties. These are usually thermotolerant and haloalkaliphilic which serve them amenable to variety of industrial processes, usually done at extreme $\mathrm{pH}$ and temperature (Setati 2010).

The presence of extreme environments in Pakistan makes it a rich source of extremophiles. Many salt mines are present in various areas of Pakistan representing the source of halophiles. Karak salt range, Kohat is one of those sites having multiple stresses such as salinity, drought and high temperature. This sample area represents excellent source of well adapted halophiles possessing great variety of efficient and stable extremozymes. In this study, we report the isolation and identification of five amylase producing halophilic bacterial strains. The most efficient strain Lactobacillus plantarum TS1 was chosen further for purification and characterization of amylase.

\section{Materials And Methods}

\section{Chemicals and Reagents}

All analytical grade reagents and chemicals were obtained from Merck, Germany and Sigma-Aldrich, USA. Nutrient Broth (LB) and minimal salt medium (MSM) along with sodium chloride was used for isolation of halophilic bacteria and agar was used as a solidifying agent. Ammonium sulphate, dialysis cassettes 
MWCO 3.5 K, DEAE-cellulose resin and Amicon purification device were used for the purification of amylase.

\section{Sampling and Isolation}

Sampling for the isolation of amylase producing salt tolerant bacterial strains was done from Karak salt range Kohat, Pakistan. Soil samples were collected, labelled and preserved at $4{ }^{\circ} \mathrm{C}$. For isolation, serial dilutions of each of the sample were made and $100 \mu \mathrm{l}$ of the sample was spread onto the nutrient agar medium ( $\mathrm{pH} 7$ ) containing $5 \%, 10 \%, 20 \%$ and $30 \%$ sodium chloride. The plates were then incubated at $37^{\circ} \mathrm{C}$ for 72 hours to get the isolated salt tolerant bacterial strains. The isolated strains were then subcultured using same conditions from which these were isolated in order to get more purified colonies (Moshfegh et al. 2013).

\section{Screening for amylase positive strains}

The isolated strains were streaked onto the starch agar medium $(\mathrm{pH} 7)$ and then incubated at $37^{\circ} \mathrm{C}$ for 24 hours for the screening of amylase positive strains. The plates were finally flooded with gram's iodine reagent to observe the zone of hydrolysis (Elmansy et al. 2018). The composition of starch agar medium includes (g/l): Starch, 10; Peptone, 5; Yeast Extract, 3; Agar, 30; and $\mathrm{NaCl}, 100$. The amylase positive strains were streaked further onto a minimal media $(\mathrm{pH} 7)$ containing starch as a sole source of carbon for confirmation. The composition of minimal medium includes (g/l): $\mathrm{NH}_{4} \mathrm{NO}_{3}, 1 ; \mathrm{NaCl}, 1 ; \mathrm{KH}_{2} \mathrm{PO}_{4}, 0.5$; $\mathrm{K}_{2} \mathrm{HPO}_{4}, 1.5 ; \mathrm{MgSO}_{4}, 0.1 ;$ Starch, 10; $\mathrm{FeSO}_{4}, 0.025$ (Kumar et al. 2012)

\section{Identification and phylogenetic analysis of Amylase Positive Strains}

The DNA of the isolated strains was extracted by using EZ-10 Spin column genomic DNA kit, (Biobasic Canada Inc). The $16 \mathrm{~S}$ rRNA genes from extracted DNA of the isolated strains were amplified by polymerase chain reaction and the PCR products were sequenced from Macrogen, Korea. NCBI Nucleotide BLAST was used to compare the 16S rRNA gene sequence of the isolated strains with closely related species. The sequences of the closely related species were retrieved for identification of the strains and to construct the phylogenetic trees. The 16S rRNA gene sequences of the identified strains were then submitted in NCBI (Asoodeh et al. 2013).

\section{Production of Amylase}

The production of amylase by each strain was accompanied in a medium containing ( $\mathrm{g} / \mathrm{l})$ : Starch, 20; Yeast Extract, 4; Peptone, 10; $\mathrm{MgSO}_{4}, 0.5 ; \mathrm{CaCl}_{2}, 0.2 ; \mathrm{NaCl}, 0.5$ (Elmansy et al. 2018). Overnight culture was used to get the seed culture of each strain and was inoculated in the medium for the production of amylase. Each strain was incubated at $37^{\circ} \mathrm{C}$ for 24 hours while shaking at $220 \mathrm{rpm}$ in shake flask incubator in a media of $50 \mathrm{ml}$ in volume. The cells were then sedimented by centrifugation at $13000 \mathrm{rpm}$ for 10 minutes at temperature of $4{ }^{\circ} \mathrm{C}$. Finally, the cell pellet was discarded, and the supernatant was used as a source of amylase (Kanimozhi et al. 2014). 


\section{Amylase Activity Assay and Total Protein Quantification}

DNS (3, 5-dinitosalicyclic acid) based assay was employed for measuring the activity of amylase. DNS react with the reducing sugar which is the product of starch and reduced into 3-amino 5-nitrosalicylic acid (ANSA) forming a adduct of reddish-brown colour with an absorbance maximum at $540 \mathrm{~nm}$. In a 1 $\mathrm{ml}$ of reaction mixture, $20 \mathrm{mM}$ phosphate buffer $\mathrm{pH} 7$ containing $120 \mathrm{mM}$ of starch along with $200 \mu \mathrm{l}$ cell free extract were added. The reaction mixture was incubated at $37^{\circ} \mathrm{C}$ for $60 \mathrm{~min}$ and then terminated by incubating at $120^{\circ} \mathrm{C}$ in furnace for about 5 minutes with addition of $1 \mathrm{ml}$ DNS. The mixture was allowed to cool at room temperature and absorbance was measured by UV/visible spectrophotometer at wavelength of $540 \mathrm{~nm}$ (Nollet and Toldrá 2009). One unit of amylase activity was defined as quantity of amylase required to produce one micro mole of glucose or maltose per unit time at its optimum conditions (Manas et al. 2014). Negative control was always used along with treated ones, that contains all the components except amylase (where the same volume of buffer was added instead of amylase) and if it has any absorbance value, it was subtracted from the treated one. Total protein concentration was measured by Bradford (1976) using bovine serum albumin as standard.

\section{Purification of Amylase}

The culture broth $(50 \mathrm{ml})$ was centrifuged at $13000 \mathrm{rpm}$ at $4{ }^{\circ} \mathrm{C}$ and the supernatant was used as enzyme source. The cell free extract was subjected to ammonium sulphate (50\% saturation) and was left overnight at $4{ }^{\circ} \mathrm{C}$. The precipitates were collected by centrifugation at $12000 \mathrm{rpm}$ and temperature of $4{ }^{\circ} \mathrm{C}$ for about 30 minutes. The precipitates obtained were finally resuspended in $2 \mathrm{ml}$ of $20 \mathrm{mM}$ phosphate buffer ( $\mathrm{pH}$ 7) (Ali et al. 2015). The concentrated enzyme was dialyzed against $20 \mathrm{mM}$ phosphate buffer (pH 7) using dialysis cassettes of molecular weight cutoff 3.5 K (Asoodeh et al. 2013). Dialysis was performed by keeping the cassette in $2 \mathrm{~L}$ buffer for two hours and after two hours the buffer was changed and again kept the cassette for next two hours and lastly it was kept for 24 hours in freshly prepared $20 \mathrm{mM}$ phosphate buffer ( $\mathrm{pH} 7)$. After dialysis the enzyme was applied to DEAE-cellulose resin ( $5 \mathrm{gm}$ in column of $3 \times 60 \mathrm{~cm}$ ) pre-equilibrated with $20 \mathrm{mM}$ phosphate $(\mathrm{pH} 7)$. The enzyme was eluted by a linear gradient of $\mathrm{NaCl}(0-0.5 \mathrm{M})$ at a flow rate of $0.5 \mathrm{ml} / \mathrm{min}$. The amylase active fractions were pooled together and re-concentrated by ultrafiltration (Moshfegh et al. 2013). Molecular weight and purity of amylase was monitored by SDS-PAGE (Sambrook and Russell 2006).

\section{Kinetic study}

Kinetic parameters of amylase were determined by using the different concentrations of starch. Reaction mixture contained various concentrations of starch ( $0 \mathrm{uM}$ to $60 \mathrm{uM})$ in $20 \mathrm{mM}$ phosphate $(\mathrm{pH}$ 9) along with purified enzyme. It was incubated up to 60 minutes and absorbance was taken after every 15 minutes. Enzyme kinetics were compared at two different temperatures i.e. at $37^{\circ} \mathrm{C}$ and $50^{\circ} \mathrm{C}$ (Shafiei et al. 2012).

\section{Characterization of Amylase at different parameters}


The optimum activity of amylase was determined at various temperatures $\left(30^{\circ} \mathrm{C}\right.$ to $\left.90{ }^{\circ} \mathrm{C}\right)$, where the reaction mixture along with enzyme was incubated at different temperatures for a period of $60 \mathrm{~min}$ (Hammami, et al. 2018). Similarly, the optimum pH of the purified amylase was assessed by incubating the reaction mixtures at various $\mathrm{pH}$ range $\left(\mathrm{pH} 2\right.$ to 12) while keeping the reaction mixture at $50{ }^{\circ} \mathrm{C}$ for 60 minutes (Shafiei et al. 2012). Negative control contained all components except amylase

\section{Effect of Temperature on Amylase Stability}

The amylase was incubated at various temperature $\left(30^{\circ} \mathrm{C}\right.$ to $\left.120^{\circ} \mathrm{C}\right)$ for about 5 minutes to determine the stability. After incubation reaction mixture was prepared by using treated amylase $(5 \mu \mathrm{l})$, starch solution $(120 \mu \mathrm{M})$ and phosphate buffer $(\mathrm{pH} 10)$. Negative control contained all components except amylase. Reaction mixture was incubated at $50^{\circ} \mathrm{C}$ for 60 minutes and activity was determined by DNS based assay (Sudan et al. 2018).

\section{Effect of Organic Solvents on Amylase Activity}

The exposure of organic solvents on amylase activity was determined by varying the buffer conditions in the assay to include 0-30 \% (V/V) ethanol, methanol, hexane, isoamyl alcohol and acetone (Sudan et al. 2018).

\section{Effect of Sodium Chloride on Amylase Activity}

The amylase was exposed to various concentrations of sodium chloride i.e. 0 to $4 \mathrm{M}$. The reaction mixture along with various concentrations of $\mathrm{NaCl}(0$ to $4 \mathrm{M})$ was incubated at $50^{\circ} \mathrm{C}$ and the activity was monitored as mentioned above (Nithya et al. 2017).

Table1: Kinetic parameters of amylase at various temperature

\begin{tabular}{|lll|}
\hline & \multicolumn{2}{l|}{ Kinetics at two temperatures } \\
\hline & $\mathbf{3 7 ^ { \circ } \mathrm { C }}$ & $\mathbf{5 0 ^ { \circ } \mathrm { C }}$ \\
\hline$K_{\text {cat }}\left(\mathrm{min}^{-1}\right)$ & 353.74 & 1236.17 \\
\hline$K_{\text {cat }}\left(\mathbf{s}^{-1}\right)$ & 5.89 & 20.61 \\
\hline$K_{M}(\mu \mathrm{M})$ & 51.67 & 28.29 \\
\hline$K_{c a t} / K_{M}\left(\mathbf{s}^{-1} \cdot \mathrm{M}^{-1}\right)$ & $1.2 \times 10^{5}$ & $7.3 \times 10^{5}$ \\
\hline
\end{tabular}

\section{Results And Discussion}




\section{Isolation and Screening}

Initially 33 bacterial strains were isolated at various concentrations of salt i.e $20 \%, 10 \%$ and $5 \%$. Out of these only five strains were found to be active to hydrolyse starch showing a clear zone of hydrolysis on starch agar plates when flooded with Gram's iodine reagent which clearly indicates the extracellular production of amylase by the selected bacterial strains. In minimal medium all five strains were able to utilize starch as a sole carbon source which further confirmed that the selected strains are amylase positive. All these five strains were identified by $16 \mathrm{~S}$ rRNA and the most efficient strain was selected for amylase production. Roohi et al. (2012) isolated 21 salt tolerant strains belong to genera Bacillus and Staphylococcus have amylase activity. Similarly, 13 strains were isolated from Karak salt mine out of which 5 have ability to produce amylase (Rehman et al. 2015).

\section{Identification and phylogenetic analysis}

Although five strains were found to be amylase positive and were identified as Lactobacillus plantarum (TS1), Bacillus cereus (TS2), Bacillus subtilis (TS3), Staphylococcus equorum (TS4), and Arthrobacter creatinolyticus (TS5) on basis of their sequence homology. The most efficient strain TS1 was chosen for amylase production, exhibited $98 \%$ similarity with Lactobacillus plantarum SSK03. A phylogenetic tree of TS1 was constructed on the basis of BLAST results as shown in Fig 1. Lactobacillus plantarum strain TS1 can be classified as moderate halophile as it is able to grow well in the presence of $10 \%$ of $\mathrm{NaCl}$ in the media.

\section{Production of Amylase}

\section{Amylase activity in various strains}

After quantifying the protein concentration in each cell free extract (CFE) obtained from different strains, the amylase activity was monitored by DNS based assay as described above.

The maximum activity was observed by amylase obtained from Lactobacillus plantarum strain TS1 as compared to other isolated strains as shown in Fig 2A and 2B. Therefore, Lactobacillus plantarum strain TS1 was selected to produce amylase, which was characterized with detailed kinetics.

\section{Purification of Amylase}

The cell free extract from Lactobacillus plantarum TS1 used as source of amylase and was purified as described above. The purity of the enzyme was monitored by SDS-PAGE and the fractions with least contaminated proteins were pooled together and further purified. The molecular weight of amylase was estimated to be $10 \mathrm{kDa}$ as shown in Fig 3.

\section{Kinetics Study}


Detailed kinetics were performed at $37^{\circ} \mathrm{C}$ as well as at $50{ }^{\circ} \mathrm{C}$. Various kinetic parameters were measured to determine the efficiency of amylase to convert starch into reducing sugars. The value of $\mathrm{K}_{\text {cat }}$ was 353.7 $\mathrm{min}^{-1}$ at $37^{\circ} \mathrm{C}$ while at $50^{\circ} \mathrm{C}$ it was increased almost four times with value of $1236.2 \mathrm{~min}^{-1}$. Similarly, the value of $K_{c a t} / K_{M}$ was high at $50{ }^{\circ} \mathrm{C}$ as compared to $37^{\circ} \mathrm{C}$ and found to be $7.3 \times 10^{5}\left(\mathrm{~s}^{-1} \cdot \mathrm{M}^{-1}\right)$ and $1.2 \times$ $10^{5}\left(\mathrm{~s}^{-1} \cdot \mathrm{M}^{-1}\right)$ respectively as shown in Table 1 . The higher value of $\mathrm{K}_{\text {cat }}$ as well as $K_{c a t} / K_{M}$ suggests that the amylase from Lactobacillus plantarum strain TS1 has high turnover at $50{ }^{\circ} \mathrm{C}$ as compare to $37^{\circ} \mathrm{C}$. Amylase obtained from various extremophile exhibit auspicious attitudes as compared to their mesophilic counter parts in extraordinary extreme conditions (Karan et al. 2012; Abdel-Fattah et al. 2013). In a recent study, amylase was purified from Halococcus designated as extreme halophile, possess unique feature and able to work efficiently in the presence of $25 \%$ (w/v) NaCl (Salgaonkar et al. 2019). In another study, amylase was characterized from the moderate halophile Halomonas meridiana that exhibited maximal activity at $37^{\circ} \mathrm{C}$ in presence of $10 \% \mathrm{NaCl}$ (Coronado et al. 2000).

\section{Characterization of Amylase}

\section{Effect of temperature on amylase activity}

Mostly the amylases obtained from halophiles retain their activity at high temperatures, so to find whether the TSA (amylase from TS1) has this property or not, the reaction mixtures was incubated at temperatures range of 30 to $90^{\circ} \mathrm{C}$. The amylase was found to be active at all these temperatures, but the maximal activity was observed at $50{ }^{\circ} \mathrm{C}$ and after that the activity was decreases gradually as shown in Fig.4. The results were quite agreed with the previous findings where the polyextremophilic properties of haloenzymes were well documented (Sinha and Khare 2014). In an earlier study, amylase was isolated from Halobacillus sp MA-2 has shown the optimum activity at $50{ }^{\circ} \mathrm{C}$ (Amoozegar et al. 2003). Similarly, a protease was isolated from Haloferax lucentensis VKMM007 have polyextremophilic properties that not only stable under high salt concentration but also active at high temperature, $\mathrm{pH}$ and even stable in presence of polar and non-polar solvents (Manikandan et al. 2009).

\section{Effect of temperature on amylase stability}

Thermostability of amylases from halophiles is another important feature that makes them valuable for industrial applications. To observe the stability of TSA at various temperature it was treated at different temperatures (30 to $120 \varangle \mathrm{C}$ ) and then activity was observed as described above. The amylase was found to be stable up till $120^{\circ} \mathrm{C}$ while the amylase treated at $90^{\circ} \mathrm{C}$ has shown greater activity as shown in Fig 5 . This result was also supported by the previous findings where thermostable amylase from halophilic strain Bacillus sp. AB68 was found to be stable at $80^{\circ} \mathrm{C}$ (Aygan et al. 2008). Temperature is one of the very critical factor that may affect the conformation of enzyme and ultimately on the affinity of enzyme with substrate, here when enzyme was treated at $90^{\circ} \mathrm{C}$ there might be some change in the structure of amylase that improves it's affınity with the substrate and that results in its increased activity (Peterson et al. 2007). 


\section{Effect of pH on amylase activity}

In order to investigate the stability of enzyme at various $\mathrm{pH}$, the reaction mixture was incubated in presence of buffers having different $\mathrm{pH}$. The results indicate that the amylase from TS1 have excellent ability to work at extremes $\mathrm{pH}$ i.e acidic and basic. Although the optimum activity was observed at $\mathrm{pH} 10$ but enzyme have capability to hydrolyse starch at $\mathrm{pH}$ of 2 as well still active at $\mathrm{pH}$ of 12 as shown in Fig 6. Mesbah and Wiegel (2018) also have the same type of findings where the alkaliphilic and halophilic amylase from Alkalilimnicola sp. NM-DCM-1 have maximal activity at $\mathrm{pH}$ of 10.5. The amylases that works in different range of $\mathrm{pH}$ are important for various industries especially that works at $\mathrm{pH}$ between 9 to 10.5 are required in detergent as well as in textile industries (Tai 2000).

\section{Effect of $\mathrm{NaCl}$ on Amylase Activity}

TSA was found to be resistant under high salt concentration and work very well in the presence of various concentrations of $\mathrm{NaCl}$. In the presence of $\mathrm{NaCl}$ in reaction mixture, amylase performed well as compare to mixture without $\mathrm{NaCl}$ as shown in Fig. 7. The optimum activity was observed when $2 \mathrm{M}$ of $\mathrm{NaCl}$ was added while in presence of 3 as well as $4 \mathrm{M}$ the activity was still high as compare to untreated sample (Fig. 7). In a previous study, amylase from halophilic bacteria Nesterenkonia sp. strain F able to tolerate wide range of salt concentrations (Moshfegh et al. 2013). Similarly, amylase from marine bacteria Saccharopolysporasp. A9 has optimum activity when $1.8 \mathrm{M} \mathrm{NaCl}$ was added in reaction mixture. In another study, amylase from halophilic strain Alkalilimnicola sp. NM-DCM-1 showed maximum activity at $2.4 \mathrm{M} \mathrm{NaCl}$ (Mesbah and Wiegel 2014). Amylases that can tolerate high concentration of $\mathrm{NaCl}$ make them more valuable for industrial applications as amylases are added in detergents to enhance stain removal ability where $\mathrm{NaCl}$ (10\% concentration) is use in high concentration in detergent formulations as a thickening agent (Showell 2016). Molecular mechanism revealed that the halophilic proteins have some unique features that enable them to survive in high concentrations of salt (Siglioccolo 2011; Tadeo X 2009). Halophilic proteins are rich in acidic amino acid residues that allow them to bind high salt concentration which were absent in their mesophilic counter parts (Ortega et al. 2015). Proteins in halophiles are generally characterized by decrease in hydrophobic amino acids frequency which contribute to form random coils instead of a-helices, all these features contribute for their function and stability (Paul S 2008).

\section{Effect of organic solvents on amylase activity}

Amylase from TS1 was fairly resistance to the presence of organic solvents. In the presence of $30 \%(\mathrm{v} / \mathrm{v})$ of ethanol or methanol the amylase was found to be active by retaining 45 to $50 \%$ activity. While the amylase from TS1 has shown less persistent when acetone, hexane and isoamyl alcohol was added in reaction mixture but still have more than $20 \%$ activity as shown in Fig 8 . Mostly the amylases from mesophiles are unable to work in the presence of organic solvents (Khajeh and Nemat-Gorgani 2001) as compare to the amylases isolated from the extreme environment. In a previous study, amylase was purified from halophilic strain Amphibacillus sp. NM-Ra2 found to be active in the presence of $25 \%(\mathrm{v} / \mathrm{v})$ of methanol, ethanol and benzene (Mesbah and Wiegel, 2014). The presence of organic solvents 
seemingly hostile for enzymes but it has been discovered that certain enzymes can catalyse more effectively in the presence of organic solvents which were impossible in water and it is because of enzyme selectivity, including substrate selectivity, stereoselectivity and chemoselectivity (Klipanov 2001).

Such may be the case of TSA that catalyse very efficiently in the presence of high organic solvents till the concentration of $20 \%(\mathrm{v} / \mathrm{v})$ but after that concentration the activity was decreased which may due to some structural change in TSA especially at its catalytic site.

\section{Conclusion}

The above results suggest the robust nature of TS1 amylase (TSA) that can tolerate extreme conditions such as $\mathrm{pH}$ and temperature which are the unique features require for various industries. The TSA works better in the presence of $\mathrm{NaCl}$ that indicates that it gets native conformation in presence of $\mathrm{NaCl}$ as reported in other amylases isolated from halophiles (Madern, Ebel et al. 2000). The current study suggest that this enzyme is suitable for various starch-based industries due to its unique features.

\section{References}

Asoodeh A, Alemi A, Heydari A, \& Akbari J (2013) Purification and biochemical characterization of an acidophilic amylase from a newly isolated Bacillus sp. DR90. Extremophiles, 17(2), 339-348.

Ali I, Akbar A, Anwar M, Prasongsuk S, Lotrakul P, \& Punnapayak H (2015) Purification and characterization of a polyextremophilic a-Amylase from an obligate halophilic Aspergillus penicillioides isolate and its potential for souse with detergents. BioMed research international, 2015, 68(1), 52-58.

Aygan, A, Arikan B, Korkmaz H, Dinçer S, \& Çolak Ö (2008) Highly thermostable and alkaline a-amylase from a halotolerant-alkaliphilic Bacillus sp. AB68. Brazilian Journal of Microbiology, 39(3), 547-553.

Amoozegar MA, Malekzadeh F, \& Malik K A (2003) Production of amylase by newly isolated moderate halophile, Halobacillus sp. strain MA-2. Journal of microbiological methods, 52(3), 353-359.

Abdel-FattahYR, Soliman NA, El-Toukhy NM, El-Gendi H, Ahmed RS (2012) Production, purification, and characterization of thermostable a-amylase produced by Bacillus licheniformis isolate Al20. Journal of Chemistry, 2013.

Bradford MM (1976) Rapid and sensitive method for quantitation of microgram quantities of protein utilizing principle of protein-dye binding. Analytical Biochemistry $72,248-254$.

Brininger C, Spradlin S, Cobani L, \& Evilia C (2018, December) The more adaptive to change, the more likely you are to survive: protein adaptation in extremophiles. In Seminars in cell \& developmental biology (Vol. 84, pp. 158-169). Academic Press. 
Coronado MJ, Vargas C, Hofemeister J, Ventosa A, Nieto JJ (2000) Production and biochemical characterization of an a-amylase from the moderate halophile Halomonas meridiana. FEMS microbiology letters, 183(1), 67-71.

Calimlioglu B, \& Arga KY (2014) Proteins from halophilic bacteria: purification and their applications. Protein Purification-Principles and Trends. iConcept Press Ltd.

Dalmaso GZL, Ferreira D, \& Vermelho AB (2015) Marine extremophiles: a source of hydrolases for biotechnological applications. Marine drugs, 13(4), 1925-1965.

Dumorné K, Córdova DC, Astorga-Eló M, \& Renganathan P (2017) Extremozymes: a potential source for industrial applications. Journal of Microbiology and Biotechnology, 27(4), 649-659.

Elmansy EA, Asker MS, El-Kady EM, Hassanein SM, \& Fawkia M (2018) Production and optimization of aamylase from thermo-halophilic bacteria isolated from different local marine environments. Bulletin of the National Research Centre, 42(1), 31.

Gomes J, \& Steiner W (2004) The biocatalytic potential of extremophiles and extremozymes. Food technology and Biotechnology, 42(4), 223-235.

Hammami A, Fakhfakh N, Abdelhedi O, Nasri M, \& Bayoudh A (2018) Proteolytic and amylolytic enzymes from a newly isolated Bacillus mojavensis SA: characterization and applications as laundry detergent additive and in leather processing. International journal of biological macromolecules, 108, 56-68.

Irwin JA, \& Baird AW (2004) Extremophiles and their application to veterinary medicine. Irish veterinary journal, 57(6), 348.

Kanimozhi M, Johny M, Gayathri N, \& Subashkumar R (2014). Optimization and production of a-amylase from halophilic Bacillus species isolated from Mangrove soil sources. Journal of Applied and Environmental Microbiology, 2, 70-73.

Karan R, Capes MD, DasSarma S (2012) Function and biotechnology of extremophilic enzymes in low water activity. Aquatic Biosystems, 8(1), 4.

Khajeh K, Nemat-Gorgani M (2001). Comparative studies on a mesophilic and a thermophilic aamylase. Applied biochemistry and biotechnology, 90(1), 47-55.

Klibanov AM (2001) "Improving enzymes by using them in organic solvents." Nature 409: 2410246.

Kumar S, Grewal J, Sadaf A, Hemamalini R, \& Khare SK (2016) Halophiles as a source of polyextremophilic a-amylase for industrial applications. AIMS Microbiology, 2, 1-26.

Kumar S, Karan R, Kapoor S, Singh SP, \& Khare SK (2012) Screening and isolation of halophilic bacteria producing industrially important enzymes. Brazilian Journal of Microbiology, 43(4), 1595-1603. 
Nollet, LM, \& Toldrá, F (Eds.) (2009) Handbook of dairy foods analysis. CRC Press.

Madern D, Ebel C, Zaccai G (2000) Halophilic adaptation of enzymes. Extremophiles, 4(2), 91-98.

Manikandan M, Pašić L, Kannan V (2009) Purification and biological characterization of a halophilic thermostable protease from Haloferax lucentensis VKMM 007. World Journal of Microbiology and Biotechnology, 25(12), 2247-2256.

Moshfegh M, Shahverdi AR., Zarrini G, \& Faramarzi MA (2013) Biochemical characterization of an extracellular polyextremophilic a-amylase from the halophilic archaeon Halorubrum xinjiangense. Extremophiles, 17(4), 677-687.

Mesbah NM, \& Wiegel J (2014) Halophilic alkali-and thermostable amylase from a novel polyextremophilic Amphibacillus sp. NM-Ra2. International journal of biological macromolecules, 70, 222229.

Mesbah NM, \& Wiegel J (2018) Improvement of Activity and Thermostability of Agar-Entrapped, Thermophilic, Haloalkaliphilic Amylase AmyD8. Catalysis Letters, 148(9), 2665-2674.

Manas NHA, Pachelles S, Mahadi NM \& Illias R M (2014) The characterisation of an alkali-stable maltogenic amylase from Bacillus lehensis $\mathrm{G} 1$ and improved malto-oligosaccharide production by hydrolysis suppression. PloS one, 9(9), e106481.

Nithya K, Muthukumar C, Kadaikunnan S, Alharbi NS, Khaled JM, \& Dhanasekaran, D (2017) Purification, characterization, and statistical optimization of a thermostable a-amylase from desert actinobacterium Streptomyces fragilis DA7-7. 3 Biotechnology, 7(5), 350.

Ortega G, Diercks T, Millet O (2015) Halophilic protein adaptation results from synergistic residue-ion interactions in the folded and unfolded states. Chemistry \& biology 22(12), 1597-1607.

Paul S, Bag SK, Das S, Harvill ET, Dutta C (2008) Molecular signature of hypersaline adaptation: insights from genome and proteome composition of halophilic prokaryotes. Genome biology, 9(4), R70.

Peterson ME, Daniel RM, Danson MJ, Eisenthal R (2007) The dependence of enzyme activity on temperature: determination and validation of parameters. Biochemical Journal, 402(2), 331-337.

Perez-Pomares F, Bautista V, Ferrer J, et al (2003) Alpha-amylase activity from the halophilic archaeon Haloferax mediterranei. Extremophiles 7: 299-306.

Roohi A, Ahmed I, Iqbal M, \& Jamil M (2012) Preliminary isolation and characterization of halotolerant and halophilic bacteria from salt mines of Karak, Pakistan. Pakistan Journal of Botany 44(SI 1), 365-370.

Roohi A, Ahmed I, Paek J, Sin Y, Abbas S, Jamil M, \& Chang YH (2014) Bacillus pakistanensis sp. nov., a halotolerant bacterium isolated from salt mines of the Karak Area in Pakistan. Antonie Leeuwenhoek 105 
(6), 11631172.

Rahman KU, Zeb A, Daud M, Ali F, et al (2015) Screening, identification and Biochemical analysis of Amylase producing Bacteria from Salt Mines of Karak, Khyber Pakhtoonkhwa, Pakistan Journal of Biodiversity and Environmental Sciences 7 (5), 1-7.

Rothschild LJ, Mancinelli RL (2001) Life in extreme environments. Nature 409:1092-1101.

Rajagopalan G, Krishnan C (2008) a-Amylase production from catabolite derepressed Bacillus subtilis KCC103 utilizing sugarcane bagasse hydrolysate. Bioresource technology, 99(8), 3044-3050.

Showell M (Ed.) (2016) Handbook of detergents, part D: formulation (128) CRC Press.

Sudan SK, Kumar N, Kaur I, Sahni, G (2018) Production, purification and characterization of raw starch hydrolyzing thermostable acidic a-amylase from hot springs, India. International journal of biological macromolecules 117, 831-839.

Shafiei M, Ziaee AA, Amoozegar MA (2012) Purification and characterization of a halophilic a-amylase with increased activity in the presence of organic solvents from the moderately halophilic Nesterenkonia sp. strain F. Extremophiles 16(4), 627-635.

Sambrook J, Russell DW (2006) SDS-polyacrylamide gel electrophoresis of proteins. CSH Protocols, 2006(4), pdb-prot4540.

Setati ME (2010) Diversity and Industrial Potential of Hydrolase Producing Halophilic/ Halotolerant Eubacteria. African Journal of Biotechnology 9 (11), 1555-1560.

Salgaonkar BB, Sawant DT, Harinarayanan S, Bragança JM (2019) Alpha-amylase Production by Extremely Halophilic Archaeon Halococcus Strain GUVSC8. Starch-Stärke 71(5-6), 1800018.

Siglioccolo A, Paiardini A, Piscitelli M, Pascarella S (2011) "Structural adaptation of extreme halophilic proteins through decrease of conserved hydrophobic contact surface." BMC Structural Biology 11(50).

Sinha R, Khare SK (2014) Protective role of salt in catalysis and maintaining structure of halophilic proteins against denaturation. Frontiers in Microbiology 5, 165.

Tadeo X, López-Méndez B, Trigueros T, Laín A, Castaño D, Millet O (2009) Structural basis for the aminoacid composition of proteins from halophilic archea. PLoS biology 7(12).

Tai LHT (2000) Formulating Detergents and Personal Care Products: A Complete Guide to Product Development. American Oil Chemists' Society.

Ulukanli Z, Digrak M (2002) Alkaliphilic micro-organisms and habitats. Turkish Journal of Biology 26:181-191. 
Wang X, Kan G, Shi C et al (2019) Purification and characterization of a novel wild-type a-amylase from Antarctic sea ice bacterium Pseudoalteromonas sp. M175. Protein expression and purification,164, 105444.

\section{Figures}

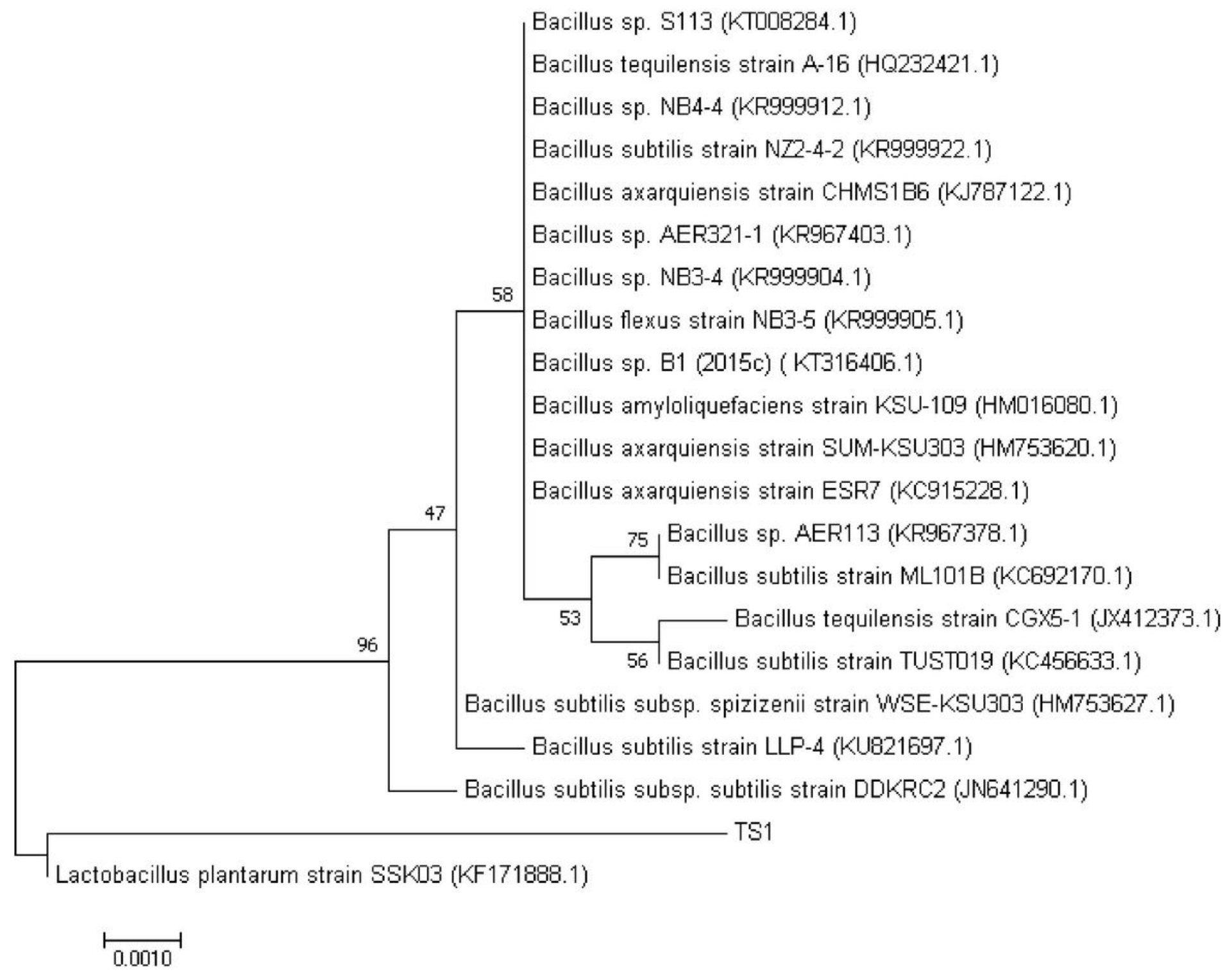

\section{Figure 1}

Neighbor-joining phylogenetic tree of the representative bacterial strain TS1 and its related species based on the $16 \mathrm{~S}$ rRNA gene sequences 
A

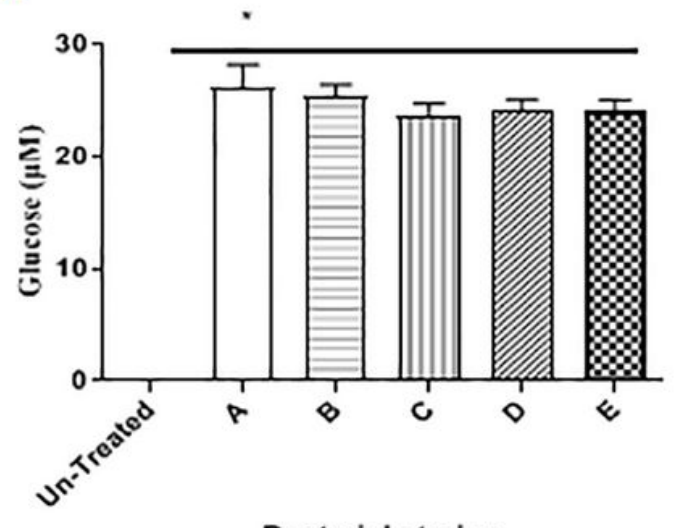

B

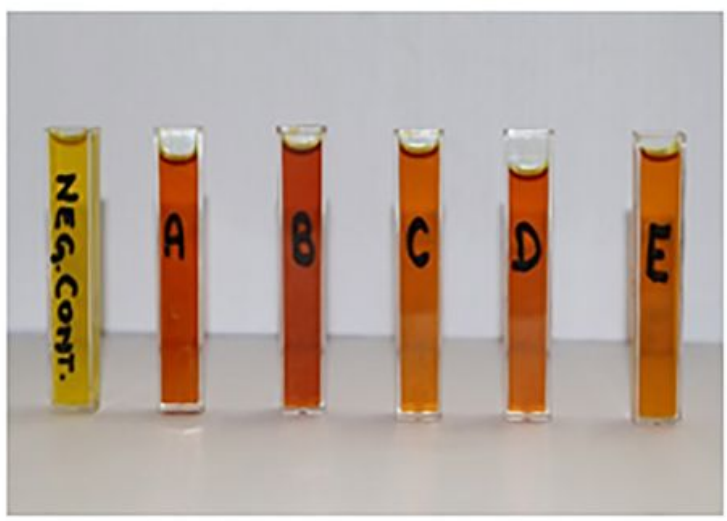

\section{Figure 2}

A. Comparison of activity of isolated strains by DNS Assay; B. DNS based Assay of five isolated strains; ("A" stands for Lactobacillus plantarum TS1, “B” for Bacillus cereus TS2, "C" Bacillus subtilis TS3, "D" for Staphylococcus equorum TS4, "E" for Arthrobacter creatinolyticus TS5 and Un-treated means where no enzyme was added) 


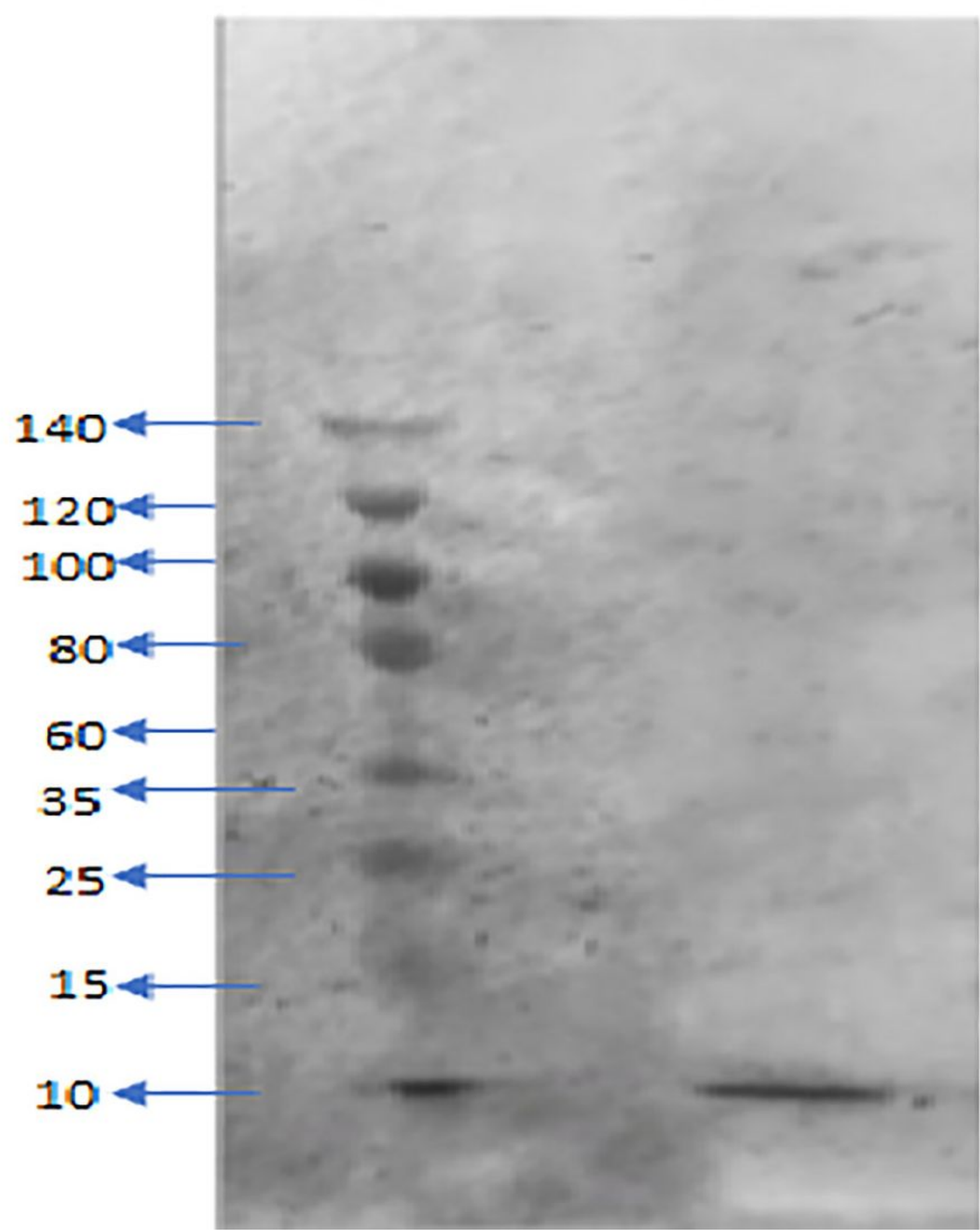

Figure 3

SDS-PAGE Gel showing bands of CFE (Cell free extract), F1 (Fraction 1), F2 (Fraction 2) and F3 (Fraction 3), M (Protein Marker) 


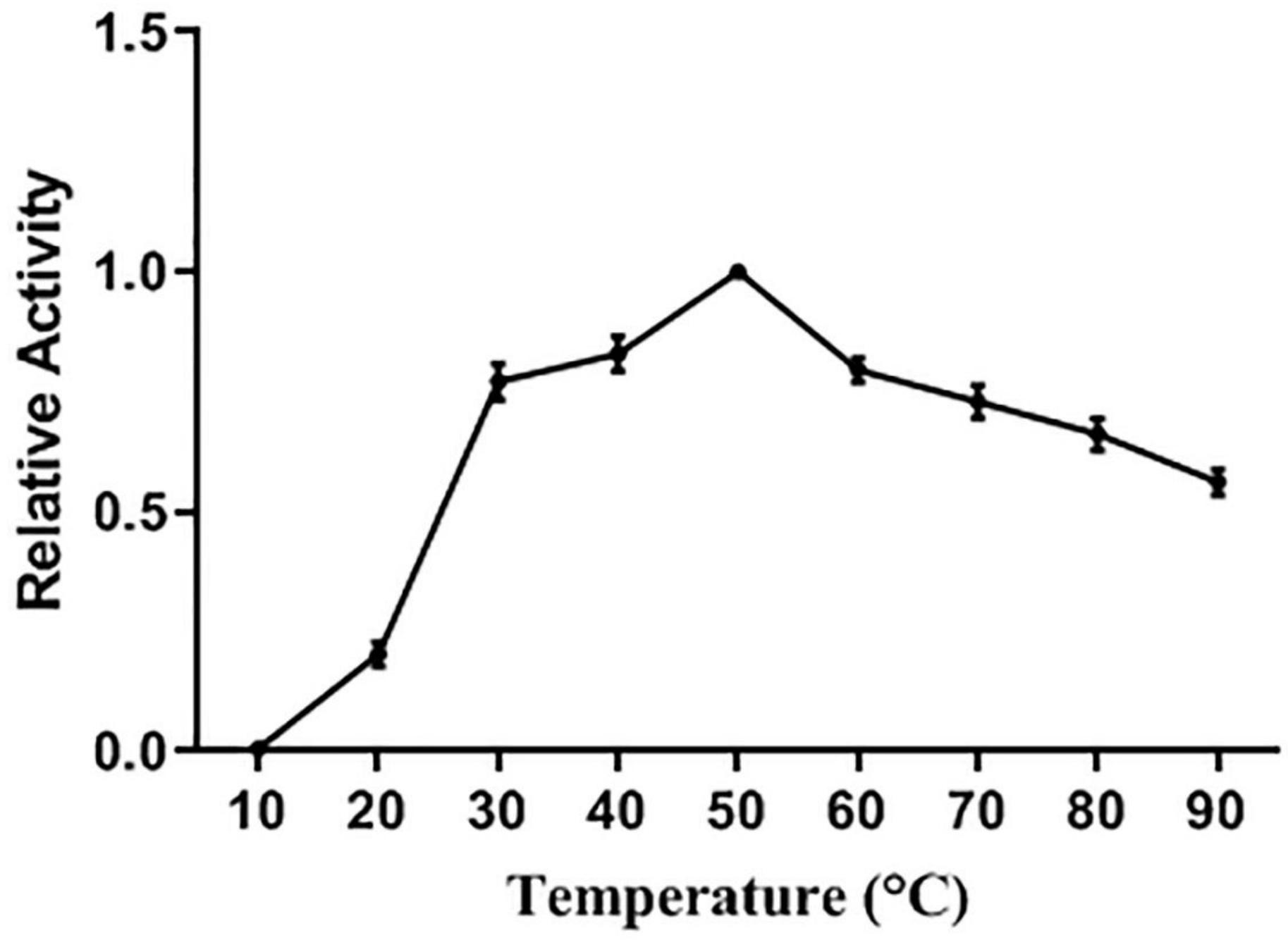

Figure 4

Relative activities of amylase at various temperatures 


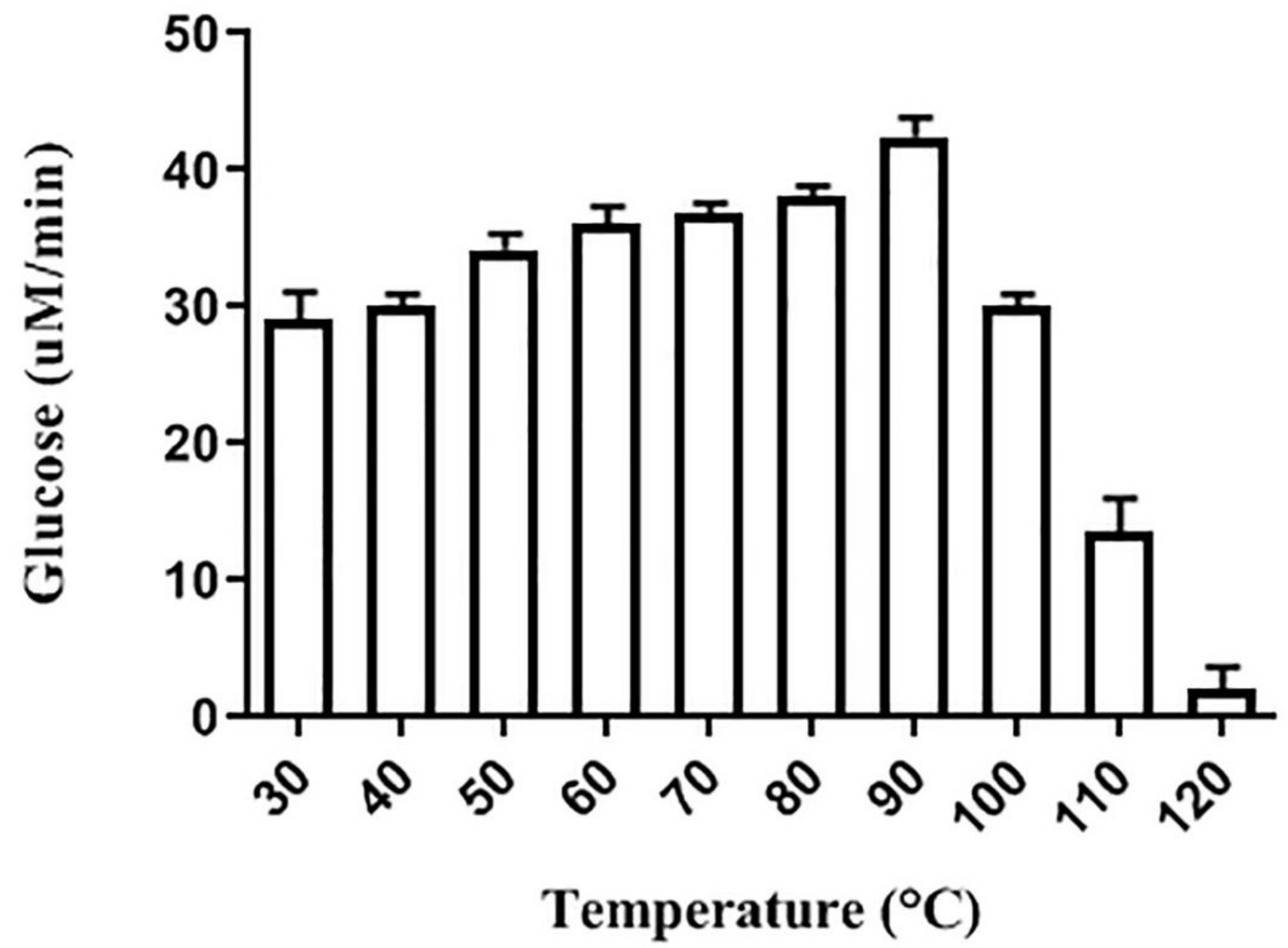

Figure 5

Effect of different temperatures on amylase stability 


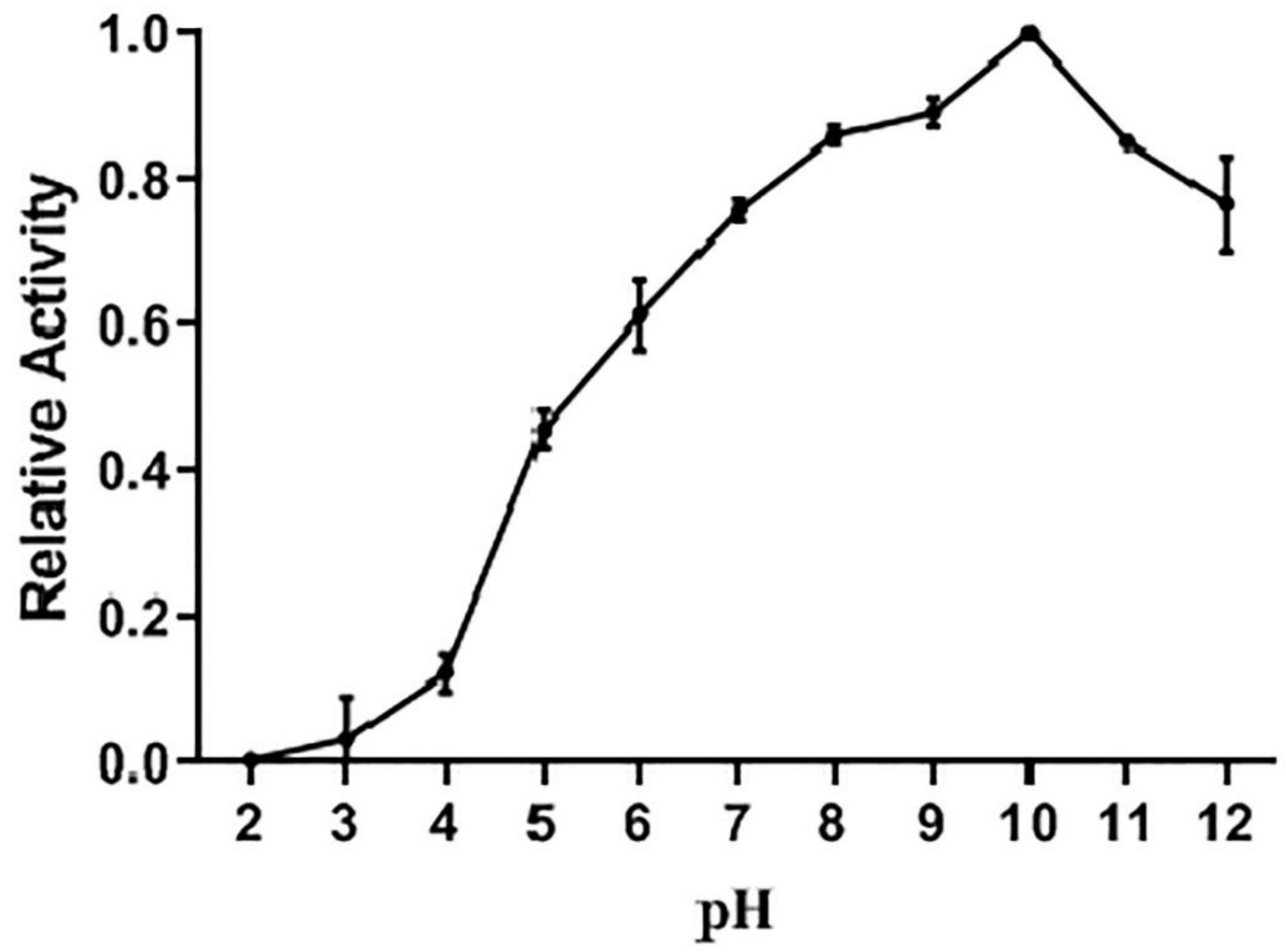

Figure 6

Relative activities of amylase at different $\mathrm{pH}$ 


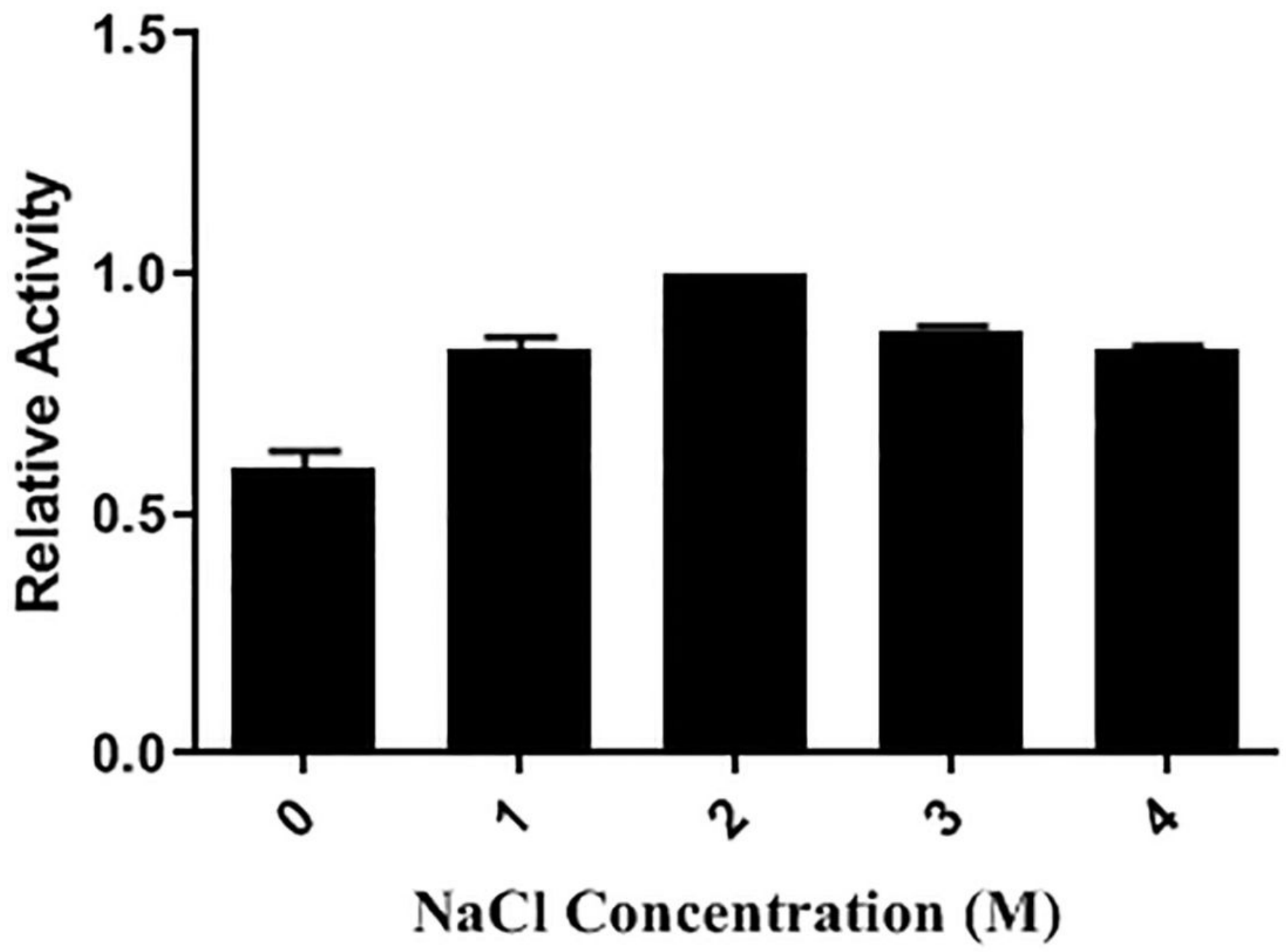

Figure 7

Relative activities of amylase in Presence of various concentrations of $\mathrm{NaCl}$ (1-4 M) 


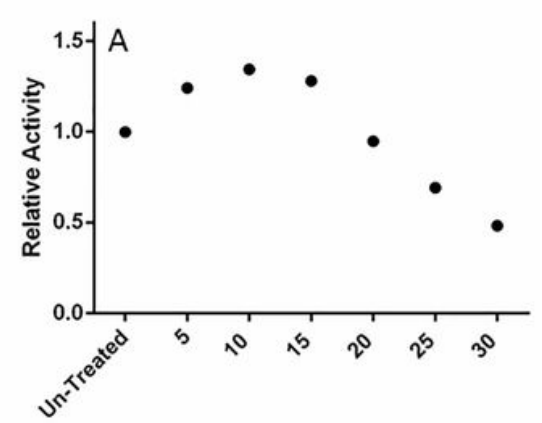

Ethanol (\% V/V)

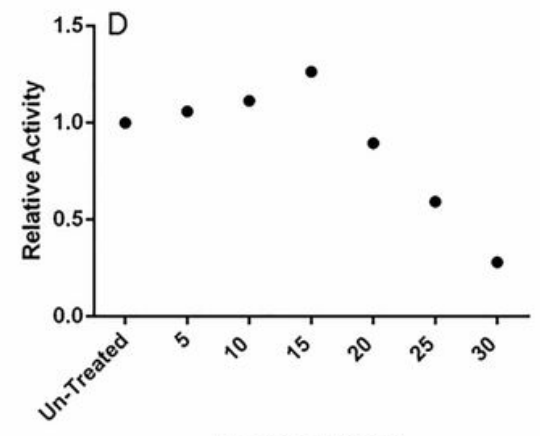

Acetone (\% VN)

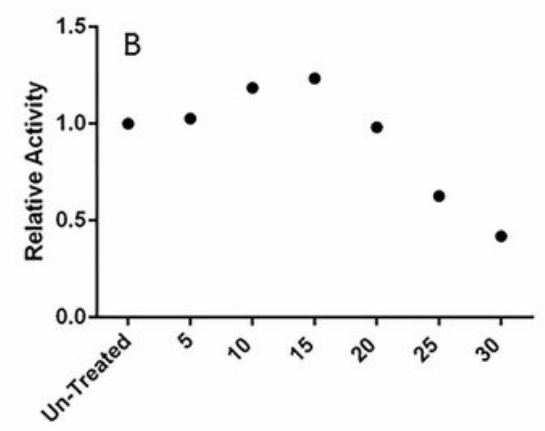

Methanol ( \% VN)

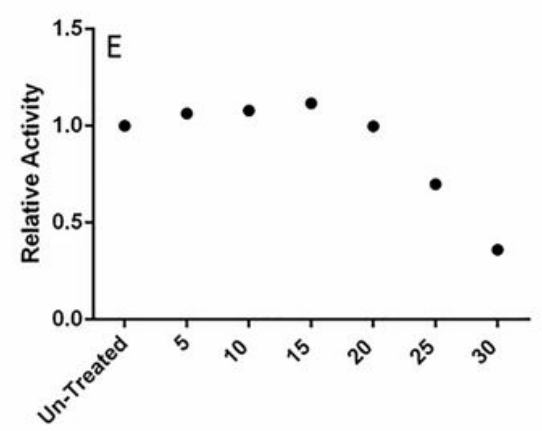

Hexane (\% VN)

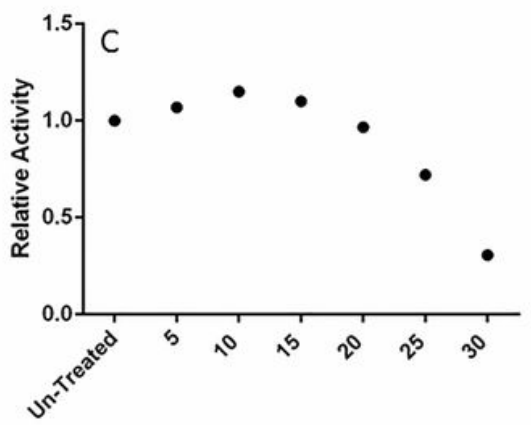

Isoamyl alcohol (\% V/V)

\section{Figure 8}

Relative activities of amylase in the presence of various organic solvents (A: Ethanol, B: Methanol, C: Isoamyl alcohol, D: Acetone, E: Hexane). 